\title{
Assessment of Trace Metal Contamination of Sediments in the Lubumbashi River Basin, Kafubu, Kimilolo and Kinkalabwamba Rivers in Lubumbashi City, Democratic Republic of Congo
}

\author{
Bamba Bukengu Muhaya ${ }^{1}$, Matthieu Kayembe wa Kayembe ${ }^{2}$, Clarisse Zoza Kunyonga ${ }^{3}$, Sonia Catherine \\ Mulongo ${ }^{4}$ and Fidele Mushagalusa $\mathrm{Cuma}^{5}$ \\ 1. Department of Chemistry, Faculty of Science, Lubumbashi University, P.O. Box 1825 Lubumbashi, D.R. Congo \\ 2. Department of Geography, Faculty of Science, Lubumbashi University, P.O. Box 1825 Lubumbashi, D.R. Congo \\ 3. Department of Material Engineering, Higher School of Industrial Engineers, Lubumbashi University, P.O. Box 1825 Lubumbashi, \\ D.R. Congo \\ 4. Department of Geology, Faculty of Science, Lubumbashi University, P.O. Box 1825 Lubumbashi, D.R. Congo \\ 5. Department of Renewable Natural Resources Management, Faculty of Agricultural Science, Lubumbashi University, P.O. Box \\ 1825 Lubumbashi, D.R. Congo
}

\begin{abstract}
Arsenic (As), Barium (Ba), Cadmium (Cd), Cobalt (Co), Chromium (Cr), Copper (Cu), Iron (Fe), Manganese (Mn), Lead $(\mathrm{Pb})$ and $\mathrm{Zinc}(\mathrm{Zn})$ concentrations were investigated in sediments collected from sixteen sampling sites in the Lubumbashi river basin and five sites in Kafubu, Kimilolo and Kinkalabwamba rivers during February, March and April 2016. Analyses of the samples were carried out using a portable X-RFS (X-Ray Fluorescence Spectrometer). Water pH and OM (Organic Matter) content of the sediments were also determined. Trace metal toxicity risk to aquatic organisms was assessed using SQGs (Sediment Quality Guidelines)-TELs (Threshold Effect Levels) and PELs (Probable Effect Levels) - for freshwater sediments. Mean values of pH and OM ranged from 4.2 to 7.8 and from $1.27 \%$ to $6.22 \%$, respectively. The highest mean levels of trace metals in sediments were 5,438 $\mathrm{mg} \cdot \mathrm{kg}^{-1} \cdot \mathrm{dw}$ and $902.5 \mathrm{mg} \cdot \mathrm{kg}^{-1} \cdot \mathrm{dw}$ for $\mathrm{Cu}$ and $\mathrm{Co}$, respectively in Lubumbashi river 1.45 kilometer downward the Lubumbashi Slag heap, $1,534.5 \mathrm{mg} \cdot \mathrm{kg}^{-1} \cdot \mathrm{dw}$ and $342 \mathrm{mg} \cdot \mathrm{kg}^{-1} \cdot \mathrm{dw}$ for $\mathrm{Zn}$ and $\mathrm{Pb}$, respectively at the confluence of Lubumbashi and Kafubu rivers, $108,900 \mathrm{mg} \cdot \mathrm{kg}^{-1} \cdot \mathrm{dw}, 547 \mathrm{mg} \cdot \mathrm{kg}^{-1} \cdot \mathrm{dw}$ and $174.5 \mathrm{mg} \cdot \mathrm{kg}^{-1} \cdot \mathrm{dw}$ for $\mathrm{Fe}$, Ba and $\mathrm{Cr}$, respectively in Kinkalabwamba river, 531 $\mathrm{mg} \cdot \mathrm{kg}^{-1} \cdot \mathrm{dw}$ and $22 \mathrm{mg} \cdot \mathrm{kg}^{-1} \cdot \mathrm{dw}$ for $\mathrm{Mn}$ and $\mathrm{Cd}$, respectively in Kimilolo river, and $37 \mathrm{mg} \cdot \mathrm{kg}^{-1} \cdot \mathrm{dw}$ for As at the confluence of Tshondo and Lubumbashi rivers. The mean concentrations of $\mathrm{As}, \mathrm{Cd}, \mathrm{Cr}, \mathrm{Cu}, \mathrm{Pb}$ and $\mathrm{Zn}$ in the sediments exceeded the corresponding SQGs' PELvalues and could have adverse effects on aquatic organisms of those rivers. Trace metal contamination of the studied sediments might be partially attributed to natural processes, unplanned urbanization and poor waste management and mostly to abandoned and ongoing mining and ore processing activities in Lubumbashi city.
\end{abstract}

Key words: Trace metals, contamination, river sediments, $\mathrm{pH}$, organic matter, Lubumbashi city.

\section{Introduction}

Sediments have a high storage capacity of chemical pollutants [1, 2] and act as a sink for trace metals [3-7].

Corresponding author: Bamba Bukengu Muhaya, Ph.D., professor, research field: assessing and mapping the environmental and health impacts of abandoned mines in Sub-Saharan African countries.
Trace metals accumulated in sediments may persist in the environment long after their primary source has been removed [8] and create a potential for continued environmental degradation [7, 9-12] even where water column contaminant levels comply with established water quality criteria [11]. Sediment-associated trace metals represent a risk for organisms living in the 
sediments and in the water column, especially invertebrates and fish, but also for humans through human food chain [1, 3, 8, 13-15]. Sediments have been reported to be one of the most important tools to assess the contamination level of aquatic ecosystems $[1,3,5,8,14-17]$.

The origin of trace metals which accumulate in sediments is partly from natural sources through the weathering of rocks and partly from a variety of human activities, including mining, smelting, electroplating and chemical manufacturing plants, as well as domestic discharges, shipping, boating activities ... [11, 18]. In many developing countries such as D.R. Congo, millions of people do not have access to safe drinking water, especially those living in rural areas and most of the poor people in urban areas, and they largely depend on surface water for their domestic water needs [19]. As those people use rivers and streams as water source for their drinking, cooking, washing, irrigation and recreation needs, river sediments heavily polluted by trace metals represent a great risk for public health. Indeed, resuspension events from natural or anthropogenic origin can disturb the biogeochemistry of sediments and potentially result in the remobilization of trace metals from sediment particles to the water column [7, 20-23]. The use of metal polluted water for irrigation can also cause the death of crops or interfere with the uptake of essential nutrients [19, 24-26].

In the Upper-Katanga province, south-eastern D.R. Congo, factors which may be responsible for the pollution of water bodies are mainly industrial and artisanal mining and ore processing activities [27-30] as well as unplanned urbanization and population growth [31], and the easy accessibility of rivers for the disposal of untreated domestic and industrial wastes $[27,28,32]$.

The aim of the current study was to investigate trace metal contamination of sediments in the Lubumbashi river basin water courses, as well as Kafubu, Kimilolo and Kinkalabwamba rivers in
Lubumbashi city, and to compare the sediment metal levels to the sediment quality guidelines-TELs (Threshold Effect Levels) and PELs (Probable Effect Levels) - to know the possible risk of the sediment metals for aquatic organisms [33]. The Lubumbashi river basin includes Lubumbashi, Tshamalale, Kipopo, Kalubwe, Kashobwe, Kabulameshi, Munua, Tshondo, Kamalondo and Kamama rivers, as well as Tshibal channel and the adjusted Adventist spring and Tshamalale-1 quarter spring. Lubumbashi, Kimilolo and Kinkalabwamba rivers are Kafubu river tributaries. All those water courses are used without prior treatment by the people who live along them to meet their domestic, agricultural and recreational needs.

\section{Material and Methods}

\subsection{Study Area and Sampling}

The study area includes various water courses of the Lubumbashi river basin, Kafubu, Kimilolo and Kinkalabwamba rivers in Lubumbashi city. The Lubumbashi river basin includes Tshamalale, Kipopo, Kalubwe, Kashobwe, Lubumbashi, Kabulameshi, Munua, Tshondo, Kamalondo and Kamama rivers, as well as Tshibal channel, adjusted Adventist spring and Tshamalale-1 quarter spring. Waters from both springs flow into Tshamalale river. All those water courses flow through Lubumbashi, the capital city of the Upper-Katanga province in south-eastern D.R. Congo (Fig. 1).

Surface sediment samples of 25-centimeter depth were collected from sixteen sampling sites in the Lubumbashi river basin and from five sites in Kafubu, Kimilolo and Kinkalabwamba rivers. Of the twenty-one sampling sites, there were three in each of Kafubu and Kabulameshi rivers, two in each of the Kamalondo, Munua, Tshamalale and Tshondo rivers, one in each of the Kamama, Kashobwe, Kimilolo, Kinkalabwamba and Tshibal channel, as well as one sampling site at each of the adjusted Adventist spring and Tshamalale-1 quarter spring (Fig. 1) during February, March and April 2016 sampling campaigns. 


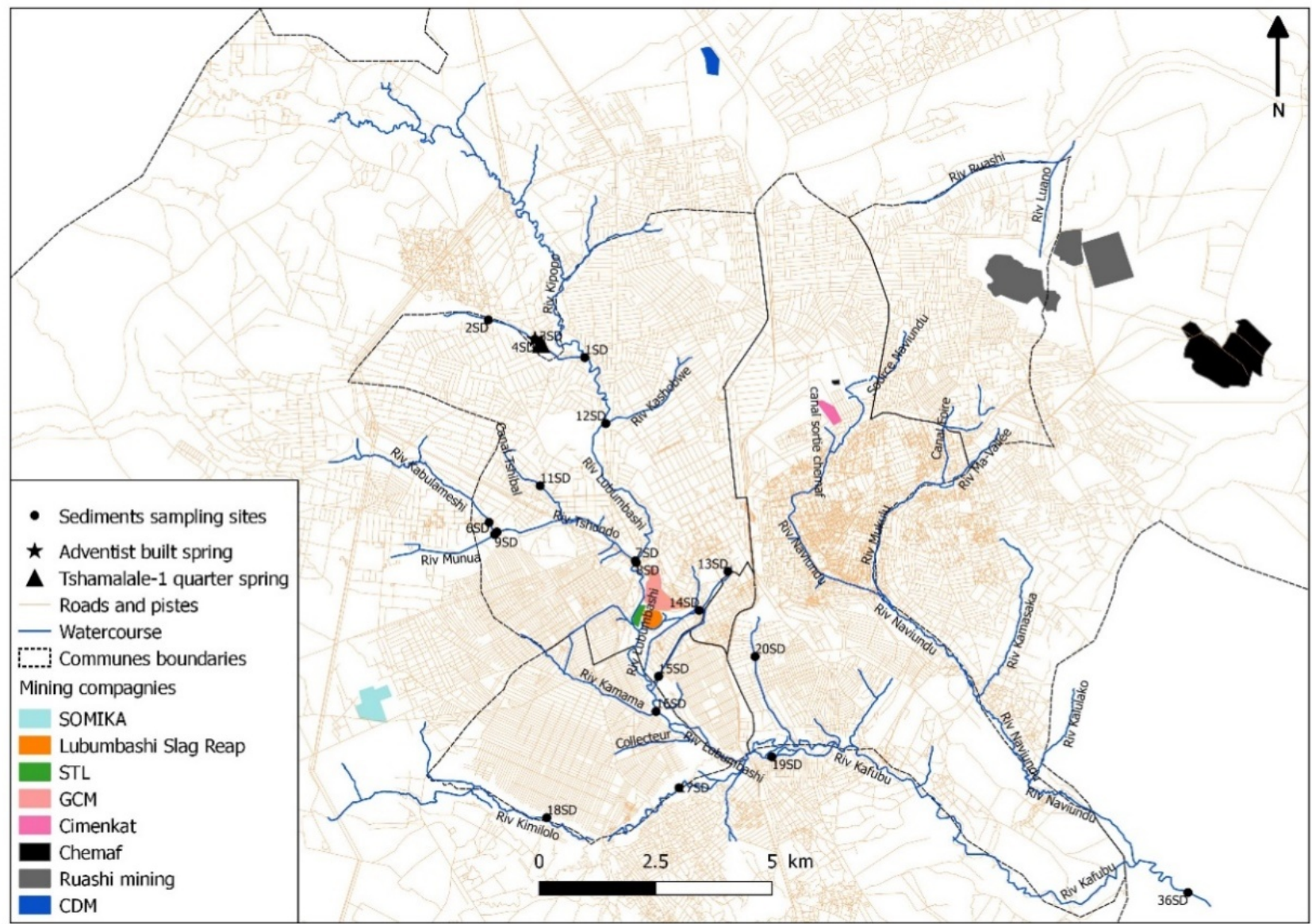

Fig. 1 Map of the river sediment sampling sites in Lubumbashi city.

A Garmin Etrex GPS was used for the determination of geographic coordinates of each sampling site. A sediment corer was used for the collection of $25-\mathrm{cm}$ deep surface sediment samples. Upon collection, each sediment sample was put in a sealed plastic bag on which a sample code was written with a permanent marker. A transparent plastic sticker was sticked on the sample code to prevent it from being erased.

\subsection{Sample Preservation}

After collection, the samples were immediately taken to the laboratory where they were stored in a deep freezer. Later on, they were thawed and dried in an oven at $35{ }^{\circ} \mathrm{C}$ for 5 days [34]. They were then grinded in a porcelain mortar and sieved trough a 2-mm sieve to obtain fine grain size. Organic matter content of the sediments was determined using the Walkley and Black method [34]. According to that method, the quantitative analysis of OM (Organic Matter) is accomplished by analyzing one of its constituents, the OC (Organic Carbon). On average, OM contains $58 \%$ OC or $\%$ OC $* 1.724=\%$ OM. The method of measuring $\mathrm{OC}$ is based on the oxidation of the latter by potassium dichromate $\left(\mathrm{K}_{2} \mathrm{Cr}_{2} \mathrm{O}_{7}\right)$ in a strong acid solution $\left(\mathrm{H}_{2} \mathrm{SO}_{4}\right)$. The grinded and sieved samples were then stored into 25-mm diameter sealed glass vials [X-RFS (X-Ray Fluorescence Spectrometer) sample cells] until they were analyzed for trace metals' content.

\subsection{Analytical Method}

The sediment samples were analyzed using an X-RFS. The accuracy and precision of the X-RFS measurements were evaluated by analyzing a standard reference material (soil). That indicated an acceptable quality of this method as a screening tool. 

Kimilolo and Kinkalabwamba Rivers in Lubumbashi City, Democratic Republic of Congo

\section{Results and Discussion}

Sediment concentrations of ten trace metals including $\mathrm{As}, \mathrm{Ba}, \mathrm{Cd}, \mathrm{Co}, \mathrm{Cr}, \mathrm{Cu}, \mathrm{Fe}, \mathrm{Mn}, \mathrm{Pb}$ and $\mathrm{Zn}$ $\left(\mathrm{mg} \cdot \mathrm{kg}^{-1} \cdot \mathrm{dw}\right), \mathrm{pH}$ and $\mathrm{OM}$ at the different sampling stations (Fig. 1), as well as the SQGs (Sediment Quality Guidelines) for freshwater sediments [33] are presented in Table 1 . Water $\mathrm{pH}$ was very acid and ranged from 4.2 to 5.5 in Tshamalale-1 quarter spring, Tshamalale river, Kafubu river 1.36 kilometer downward its confluence with Naviundu river, Munua river, Lubumbashi river at its confluence with Tshondo river, Tshondo river at its confluence with Kabulameshi river, and Kafubu river at its confluence with Lubumbashi river (Table 1). The water $\mathrm{pH}$ was acid and varied from 5.8 to 6.2 in adjusted Adventist spring, Kalubwe river at its confluence with Kipopo river, Tshibal channel, and Kabulameshi river. In Lubumbashi river 1.45 kilometer downward the Lubumbashi Slag heap, water $\mathrm{pH}$ was close to neutral with the value of 6.9. It was alkaline and varied from 7.2 to 7.8 in Kinkalabwamba river, Tshondo river, Kamalondo river near Wima Lycée, Kimilolo river, Kafubu river, Kamalondo river 60 meters from the GCM-Lubumbashi smelter (General of Quarries and Mines-Lubumbashi smelter), and Lubumbashi river at its confluence with Kamama river.

Sediment mean OM content varied from $1.27 \%$ to $6.22 \%$ (Table 1 ). They were very low in sediments of adjusted Adventist spring (1.27\%), Tshibal channel (1.30\%), Lubumbashi river 1.45 kilometer downward the Lubumbashi Slag heap (1.34\%), Kamalondo river near Wima Lycée (1.43\%), Kinkalabwamba river (1.47\%), Kabulameshi and Munua rivers' confluence $(1.99 \%)$, Kalubwe river at its confluence with Kipopo river $(2.47 \%)$, Kafubu river 1.36 kilometer downward its confluence with Naviundu river (2.53\%), Kabulameshi river (2.57\%) and Tshondo river (2.70\%). Sediments of Munua river, Kashobwe river, Tshamalale river, and Kamalondo river 60 meters from the GCM-Lubumbashi smelter had low OM content values of $3.0 \%, 3.84 \%, 3.97 \%$ and $4.0 \%$, respectively.
High OM content of sediments was noted in Lubumbashi river at its confluence with Tshondo river $(4.13 \%)$, Kimilolo river $(4.16 \%)$, Tshamalale river at its confluence with water of both springs (4.26\%), Tshamalale-1 quarter spring (4.49\%), Kafubu river (4.75\%), Lubumbashi river at its confluence with Kamama river $(5.05 \%)$ and Kafubu river at its confluence with Lubumbashi river (6.22\%).

Trace metal concentrations in sediments of the different rivers are compared to the sediment quality guidelines for freshwater sediments [33]. The SQGs were used to determine the possible toxic effects of the metals on aquatic organisms (Table 1). The results indicated that trace metal concentrations in sediments from most of the sampling sites largely exceeded the recommendation limits of the SQGs for the protection of aquatic life. The highest mean trace metal concentrations were recorded in sediments of Lubumbashi river $\left(29-45 \mathrm{mg} \cdot \mathrm{kg}^{-1} \cdot \mathrm{dw}\right.$ for As, 2,739-6,941 $\mathrm{mg} \cdot \mathrm{kg}^{-1} \cdot \mathrm{dw}$ for $\mathrm{Cu}, 127-278 \mathrm{mg} \cdot \mathrm{kg}^{-1} \cdot \mathrm{dw}$ for $\mathrm{Pb}$ and $755-1,520 \mathrm{mg} \cdot \mathrm{kg}^{-1} \cdot \mathrm{dw}$ for $\mathrm{Zn}$ ), except $\mathrm{Cr}$ concentrations which were highest in Kinkalabwamba river sediments $\left(165-184 \mathrm{mg} \cdot \mathrm{kg}^{-1} \cdot \mathrm{dw}\right)$. The highest mean $\mathrm{Cu}$ and $\mathrm{Co}$ concentrations were recorded in Lubumbashi river sediments 1.45 kilometer downward the Lubumbashi Slag heap $\left(5,438 \mathrm{mg} \cdot \mathrm{kg}^{-1}\right.$ and 902.5 $\mathrm{mg} \cdot \mathrm{kg}^{-1}$, respectively) but the sediment OM content $(1.34 \%)$ was very low and the $\mathrm{pH}$ was below neutral (6.9). The very low OM content of the sediments and the $\mathrm{pH}$ in that river increase the metal bioavailability to organisms dwelling in those sediments. It has been reported that $\mathrm{pH}$ and organic matter are among the factors which favor heavy metal retention in soils $[30,35]$, and that organic-rich soils or sediments play, for the same reasons as those presenting alkaline $\mathrm{pH}$, the role of trapping heavy metals $[6,7,35,36]$. Those mean $\mathrm{Cu}$ and Co concentrations in Lubumbashi river sediments 1.45 kilometer downward the Lubumbashi Slag heap $\left(5,438 \mathrm{mg} \cdot \mathrm{kg}^{-1}\right.$ and 902.5 $\mathrm{mg} \cdot \mathrm{kg}^{-1}$, respectively) and that of $\mathrm{Pb}$ in sediment of Kafubu river at its confluence with Lubumbashi river 
Table 1 Mean trace metal concentrations in sediments $\left(\mathrm{mg} \cdot \mathrm{kg}^{-1} \cdot \mathrm{dw}\right)$ of the Lubumbashi river basin, Kafubu, Kimilolo and Kinkalabwamba rivers in Lubumbashi city during February, March and April 2016.

\begin{tabular}{|c|c|c|c|c|c|c|c|c|c|c|c|c|c|}
\hline Sampling site & $\begin{array}{l}\text { Sample } \\
\text { code }\end{array}$ & $\mathrm{pH}$ water & $\begin{array}{l}\mathrm{OM} \\
(\%)\end{array}$ & $\begin{array}{l}\text { As } \\
\left(\mathrm{mg} \cdot \mathrm{kg}^{-1}\right)\end{array}$ & $\begin{array}{l}\mathrm{Ba} \\
\left(\mathrm{mg} \cdot \mathrm{kg}^{-1}\right)\end{array}$ & $\begin{array}{l}\mathrm{Cd} \\
\left(\mathrm{mg} \cdot \mathrm{kg}^{-1}\right)\end{array}$ & $\begin{array}{l}\mathrm{Co} \\
\left(\mathrm{mg} \cdot \mathrm{kg}^{-1}\right)\end{array}$ & $\begin{array}{l}\mathrm{Cr} \\
\left(\mathrm{mg} \cdot \mathrm{kg}^{-1}\right)\end{array}$ & $\begin{array}{l}\mathrm{Cu} \\
\left(\mathrm{mg} \cdot \mathrm{kg}^{-1}\right)\end{array}$ & $\begin{array}{l}\mathrm{Mn} \\
\left(\mathrm{mg} \cdot \mathrm{kg}^{-1}\right)\end{array}$ & $\begin{array}{l}\mathrm{Pb} \\
\left(\mathrm{mg} \cdot \mathrm{kg}^{-1}\right)\end{array}$ & $\begin{array}{l}\mathrm{Zn} \\
\left(\mathrm{mg} \cdot \mathrm{kg}^{-1}\right)\end{array}$ & $\begin{array}{l}\mathrm{Fe} \\
\left(\mathrm{mg} \cdot \mathrm{kg}^{-1}\right)\end{array}$ \\
\hline & SQGs & & & & & & & & & & & & \\
\hline & TELs & $\mathrm{Na}$ & $\mathrm{Na}$ & 5.9 & $\mathrm{Na}$ & 0.6 & $\mathrm{Na}$ & 37.3 & 35.7 & $\mathrm{Na}$ & 35 & 123 & $\mathrm{Na}$ \\
\hline & PELs & $\mathrm{Na}$ & $\mathrm{Na}$ & 17.0 & $\mathrm{Na}$ & 3.5 & $\mathrm{Na}$ & 90.0 & 197 & $\mathrm{Na}$ & 91.3 & 315 & $\mathrm{Na}$ \\
\hline Kalubwe river & $1 \mathrm{SD}$ & 6.0 & 2.47 & ND & 222 & ND & ND & 50 & 180 & 134 & ND & 102 & 28,900 \\
\hline $\begin{array}{l}\text { Confluence of Tshamalale \& } \\
\text { Kipopo rivers }\end{array}$ & $2 \mathrm{SD}$ & 4.6 & 3.97 & ND & 382 & ND & ND & 69 & 503 & 124 & 56 & 198 & 24,900 \\
\hline Tshamalale river & $3 \mathrm{SD}$ & 4.4 & 4.26 & ND & 134 & ND & ND & ND & 120 & 182 & ND & 62.5 & 7,150 \\
\hline Adjusted Adventist spring & 4SD & 5.8 & 1.27 & ND & 170 & ND & ND & 25 & 164 & 144.5 & ND & 47 & 18,900 \\
\hline Tshamalale-1 quarter spring & $5 \mathrm{SD}$ & 4.2 & 4.49 & ND & 214.5 & ND & ND & ND & 347 & 40.5 & 27 & 64.5 & 34,900 \\
\hline Kabulameshi river & $6 \mathrm{SD}$ & 6.2 & 2.57 & ND & 466 & ND & ND & ND & 545 & 331.5 & 55.5 & 225.5 & 43,700 \\
\hline Tshondo river & 7SD & 7.4 & 2.70 & 23.5 & 468.5 & ND & ND & 33 & $3,467.5$ & 252 & 240.5 & 895.5 & 38,500 \\
\hline $\begin{array}{l}\text { Confluence of Tshondo \& } \\
\text { Lubumbashi rivers }\end{array}$ & $8 \mathrm{SD}$ & 5.1 & 4.13 & 37 & 397 & ND & ND & 26.5 & 3,304 & 433.5 & 255 & 856 & 34,200 \\
\hline Munua river & 9SD & 4.9 & 3.00 & 29.5 & 392.5 & ND & ND & 59.5 & $1,630.5$ & 171.5 & 159.5 & 481 & 53,850 \\
\hline $\begin{array}{l}\text { Confluence of Munua \& } \\
\text { Kabulameshi rivers }\end{array}$ & 10SD & 5.2 & 1.99 & 9 & 327 & ND & ND & ND & 178 & 349 & ND & 134 & 24,000 \\
\hline Tshibal channel & $11 \mathrm{SD}$ & 6.1 & 1.30 & ND & 291 & ND & ND & ND & 1321 & 139 & 79 & 787 & 45,000 \\
\hline Kashobwe river & $12 \mathrm{SD}$ & 5.9 & 3.84 & ND & 379 & ND & ND & ND & 682.5 & 219.5 & 101 & 402.5 & 33,100 \\
\hline Kamalondo river near Wima Lycée & $13 \mathrm{SD}$ & 7.5 & 1.43 & ND & 460 & ND & ND & ND & 661 & 354 & 53 & 313 & 48,400 \\
\hline $\begin{array}{l}\text { Kamalondo river } 60 \mathrm{~m} \text { from the } \\
\text { GCM-Lubumbashi smelter }\end{array}$ & $14 \mathrm{SD}$ & 7.8 & 4.0 & 9.5 & 253.5 & 18.5 & ND & ND & 946 & 297.5 & 100.5 & 655 & 25,450 \\
\hline $\begin{array}{l}\text { Lubumbashi river } 1.45 \mathrm{~km} \\
\text { downward the Lubumbashi Slag heap }\end{array}$ & $15 \mathrm{SD}$ & 6.9 & 1.34 & 16 & 348.5 & ND & 902.5 & ND & 5,438 & 339.5 & 146.5 & $1,342.5$ & 98,450 \\
\hline Kamama river & 16SD & 7.8 & 5.05 & 17 & 375.5 & ND & ND & 33 & 1,786 & 274.5 & 209 & 845,5 & 26,000 \\
\hline Kafubu river & $17 \mathrm{SD}$ & 7.7 & 4.75 & ND & 250 & ND & ND & 20.5 & 272 & 241.5 & 35.5 & 228.5 & 20,450 \\
\hline Kimilolo river & $18 \mathrm{SD}$ & 7.6 & 4.16 & 22 & 420 & ND & ND & ND & 271 & 531 & 47 & 270 & 43,350 \\
\hline $\begin{array}{l}\text { Confluence of Kafubu \& } \\
\text { Lubumbashi rivers }\end{array}$ & 19SD & 5.5 & 6.22 & ND & 472.5 & 56 & ND & ND & 3,161 & 184 & 342 & $1,534.5$ & 40,300 \\
\hline Kinkalabwamba river & 20SD & 7.2 & 1.47 & 16 & 547 & ND & ND & 174.5 & 1,070 & 347.5 & 44.5 & 371 & 108,900 \\
\hline $\begin{array}{l}\text { Kafubu river } 1.3 \mathrm{~km} \text { downward its } \\
\text { confluence with Naviundu river }\end{array}$ & $36 \mathrm{SD}$ & 4.5 & 2.53 & 21.5 & 396.5 & ND & ND & ND & 185.5 & 152.5 & 14 & 418.5 & 37,350 \\
\hline
\end{tabular}

SQGs: Sediment Quality Guidelines (Canadian Council of Ministers of the Environment, 2001); PELs: probable effect levels refer to concentration levels above which adverse effects are likely to occur; TELs: threshold effect levels represent concentrations below which a toxic effect on aquatic organisms will rarely occur; dw: dry weight; Na: no available data; ND: not detected; OM: organic matter; SD: sediment. 

Kimilolo and Kinkalabwamba Rivers in Lubumbashi City, Democratic Republic of Congo

(342 $\left.\mathrm{mg} \cdot \mathrm{kg}^{-1}\right)$ were lower than those $\left(47,468 \mathrm{mg} \cdot \mathrm{kg}^{-1}\right.$, $13,199 \mathrm{mg} \cdot \mathrm{kg}^{-1}$ and $851.9 \mathrm{mg} \cdot \mathrm{kg}^{-1}$, respectively) reported for surface sediments of Luilu river [27], but they were higher than the $\mathrm{Cu}, \mathrm{Co}$ and $\mathrm{Pb}$ levels $(370.8$ $\mathrm{mg} \cdot \mathrm{kg}^{-1}, 240.6 \mathrm{mg} \cdot \mathrm{kg}^{-1}$ and $5.5 \mathrm{mg} \cdot \mathrm{kg}^{-1}$, respectively) noted in sediments of Musonoie river in the Kolwezi district (Lualaba province, D.R. Congo) [27]. Following the recommendation limits of the Canadian SQGs for the protection of aquatic life, the TELs (concentrations below which a toxic effect on aquatic organisms will rarely occur) and the PELs (concentration levels above which adverse effects are likely to occur) [33] are respectively $5.9 \mathrm{mg} \cdot \mathrm{kg}^{-1}$ and $17.0 \mathrm{mg} \cdot \mathrm{kg}^{-1}$ for As, $37.3 \mathrm{mg} \cdot \mathrm{kg}^{-1}$ and $90.0 \mathrm{mg} \cdot \mathrm{kg}^{-1}$ for $\mathrm{Cr}, 35.7 \mathrm{mg} \cdot \mathrm{kg}^{-1}$ and $197 \mathrm{mg} \cdot \mathrm{kg}^{-1}$ for $\mathrm{Cu}, 35$ $\mathrm{mg} \cdot \mathrm{kg}^{-1}$ and $91.3 \mathrm{mg} \cdot \mathrm{kg}^{-1}$ for $\mathrm{Pb}$ and $123 \mathrm{mg} \cdot \mathrm{kg}^{-1}$ and $315 \mathrm{mg} \cdot \mathrm{kg}^{-1}$ for $\mathrm{Zn}$ (Table 1).

Mean sediment trace metal levels above the SQGs' PEL values were recorded at different sampling sites. This was the case for As in sediments of Kafubu river $\left(21.5 \mathrm{mg} \cdot \mathrm{kg}^{-1} \cdot \mathrm{dw}\right)$, Kimilolo river $\left(22.0 \mathrm{mg} \cdot \mathrm{kg}^{-1} \cdot \mathrm{dw}\right)$, Tshondo river $\left(23.5 \mathrm{mg} \cdot \mathrm{kg}^{-1} \cdot \mathrm{dw}\right)$, Munua river $(29.5$ $\mathrm{mg} \cdot \mathrm{kg}^{-1} \cdot \mathrm{dw}$ ), and at the confluence of Tshondo river with Lubumbashi river $\left(37.0 \mathrm{mg} \cdot \mathrm{kg}^{-1} \cdot \mathrm{dw}\right)$, for $\mathrm{Cd}$ in sediments of Kamalondo river near Wima Lycée (16.5 $\left.\mathrm{mg} \cdot \mathrm{kg}^{-1} \cdot \mathrm{dw}\right)$, and at the confluence of Lubumbashi and Kafubu rivers (56 $\mathrm{mg} \cdot \mathrm{kg}^{-1} \cdot \mathrm{dw}$ ) (Table 1, Fig. 2). That was also the case for $\mathrm{Cr}$ in Kinkalabwamba river sediments $\left(174.5 \mathrm{mg} \cdot \mathrm{kg}^{-1} \cdot \mathrm{dw}\right)$, for $\mathrm{Cu}$ in sediments at all the sampling sites, except in Kalubwe river, adjusted Adventist spring and Tshamalale-1 quarter spring (Table 1, Fig. 2). Mean $\mathrm{Pb}$ concentrations higher than the SQGs' PEL value of $91.3 \mathrm{mg} \cdot \mathrm{kg}^{-1} \cdot \mathrm{dw}$ were recorded in sediment samples from Kamalondo river 60 meters from the GCM-Lubumbashi smelter (100.5 $\left.\mathrm{mg} \cdot \mathrm{kg}^{-1} \cdot \mathrm{dw}\right)$, Kashobwe river (101 $\left.\mathrm{mg} \cdot \mathrm{kg}^{-1} \cdot \mathrm{dw}\right)$, Lubumbashi river 1.45 kilometer downward the Lubumbashi Slag heap (146.5 $\left.\mathrm{mg} \cdot \mathrm{kg}^{-1} \cdot \mathrm{dw}\right)$, Munua river $\left(159.5 \mathrm{mg} \cdot \mathrm{kg}^{-1} \cdot \mathrm{dw}\right)$, Kamama and Lubumbashi rivers' confluence (209 $\left.\mathrm{mg} \cdot \mathrm{kg}^{-1} \cdot \mathrm{dw}\right)$, Tshondo river $\left(240.5 \mathrm{mg} \cdot \mathrm{kg}^{-1} \cdot \mathrm{dw}\right)$,
Tshondo and Lubumbashi rivers' confluence (255 $\left.\mathrm{mg} \cdot \mathrm{kg}^{-1} \cdot \mathrm{dw}\right)$, and Lubumbashi and Kafubu rivers' confluence (342 $\mathrm{mg} \cdot \mathrm{kg}^{-1} \cdot \mathrm{dw}$ ) (Table 1, Fig. 2). The sediment mean concentrations of $\mathrm{Cr}$ and $\mathrm{Fe}$ in Kinkalabwamba river $\left(174.5 \mathrm{mg} \cdot \mathrm{kg}^{-1} \cdot \mathrm{dw}\right.$ and 108,900 $\mathrm{mg} \cdot \mathrm{kg}^{-1} \cdot \mathrm{dw}$ ), respectively and that of $\mathrm{Zn}$ in Lubumbashi river 1.45 kilometer downward the Lubumbashi Slag heap $\left(1,342.5 \mathrm{mg} \cdot \mathrm{kg}^{-1} \cdot \mathrm{dw}\right)$ were higher than the highest concentrations respectively noted in Luilu river $\left(69.3 \mathrm{mg} \cdot \mathrm{kg}^{-1} \cdot \mathrm{dw}\right.$ and 116.4 $\left.\mathrm{mg} \cdot \mathrm{kg}^{-1} \cdot \mathrm{dw}\right)$ and Musonoie river $\left(24.6 \mathrm{mg} \cdot \mathrm{kg}^{-1} \cdot \mathrm{dw}\right.$ and $14.5 \mathrm{mg} \cdot \mathrm{kg}^{-1} \cdot \mathrm{dw}$ ) [27].

Mean concentrations of $\mathrm{Zn}$ in sediments of Kinkalabwamba river $\left(371 \mathrm{mg} \cdot \mathrm{kg}^{-1} \cdot \mathrm{dw}\right)$, Kashobwe river (402.5 $\left.\mathrm{mg} \cdot \mathrm{kg}^{-1} \cdot \mathrm{dw}\right)$, Kafubu river 1.36 kilometer downward its confluence with Naviundu river (418.5 $\left.\mathrm{mg} \cdot \mathrm{kg}^{-1} \cdot \mathrm{dw}\right)$, Munua river $\left(481 \mathrm{mg} \cdot \mathrm{kg}^{-1} \cdot \mathrm{dw}\right)$, Kamalondo river 60 meters from the GCM-Lubumbashi smelter $\left(655 \mathrm{mg} \cdot \mathrm{kg}^{-1} \cdot \mathrm{dw}\right)$, Tshibal channel $(787$ $\left.\mathrm{mg} \cdot \mathrm{kg}^{-1} \cdot \mathrm{dw}\right)$, confluence of Kamama and Lubumbashi rivers $\left(845.5 \mathrm{mg} \cdot \mathrm{kg}^{-1} \cdot \mathrm{dw}\right)$, and that of Tshondo and Lubumbashi rivers $\left(856 \mathrm{mg} \cdot \mathrm{kg}^{-1} \cdot \mathrm{dw}\right)$, Tshondo river (895.5 $\mathrm{mg} \cdot \mathrm{kg}^{-1} \cdot \mathrm{dw}$ ), Lubumbashi river 1.45 kilometer downward the Lubumbashi Slag heap $(1,342.5$ $\left.\mathrm{mg} \cdot \mathrm{kg}^{-1} \cdot \mathrm{dw}\right)$, and the confluence of Lubumbashi and Kafubu rivers $\left(1,534.5 \mathrm{mg} \cdot \mathrm{kg}^{-1} \cdot \mathrm{dw}\right)$ were higher than the SQGs' PEL value of $315 \mathrm{mg} \cdot \mathrm{kg}^{-1}$ (Table 1, Fig. 3). Mean Cr levels of sediments were $50 \mathrm{mg} \cdot \mathrm{kg}^{-1} \cdot \mathrm{dw}$ at the confluence of Kipopo and Kalubwe rivers, 69 $\mathrm{mg} \cdot \mathrm{kg}^{-1} \cdot \mathrm{dw}$ in Tshamalale river, $25 \mathrm{mg} \cdot \mathrm{kg}^{-1} \cdot \mathrm{dw}$ in the adjusted Adventist spring, $33 \mathrm{mg} \cdot \mathrm{kg}^{-1} \cdot \mathrm{dw}$ in Tshondo river, $26.5 \mathrm{mg} \cdot \mathrm{kg}^{-1} \cdot \mathrm{dw}$ at the confluence of Tshondo and Lubumbashi rivers, $59.5 \mathrm{mg} \cdot \mathrm{kg}^{-1} \cdot \mathrm{dw}$ in Munua river, $33 \mathrm{mg} \cdot \mathrm{kg}^{-1} \cdot \mathrm{dw}$ at the confluence of Kamama and Lubumbashi rivers, $20.5 \mathrm{mg} \cdot \mathrm{kg}^{-1} \cdot \mathrm{dw}$ in Kafubu river, and $174.5 \mathrm{mg} \cdot \mathrm{kg}^{-1} \cdot \mathrm{dw}$ in Kinkalabwamba river, but that metal was not detected in sediments of the other studied rivers, channel and spring. The mean $\mathrm{Cr}$ concentrations in sediments of Munua, Tshamalale and Kinkalabwamba rivers were higher than those reported for sediments of Mvudi river, south Africa [3]. The $\mathrm{Cu}$, 


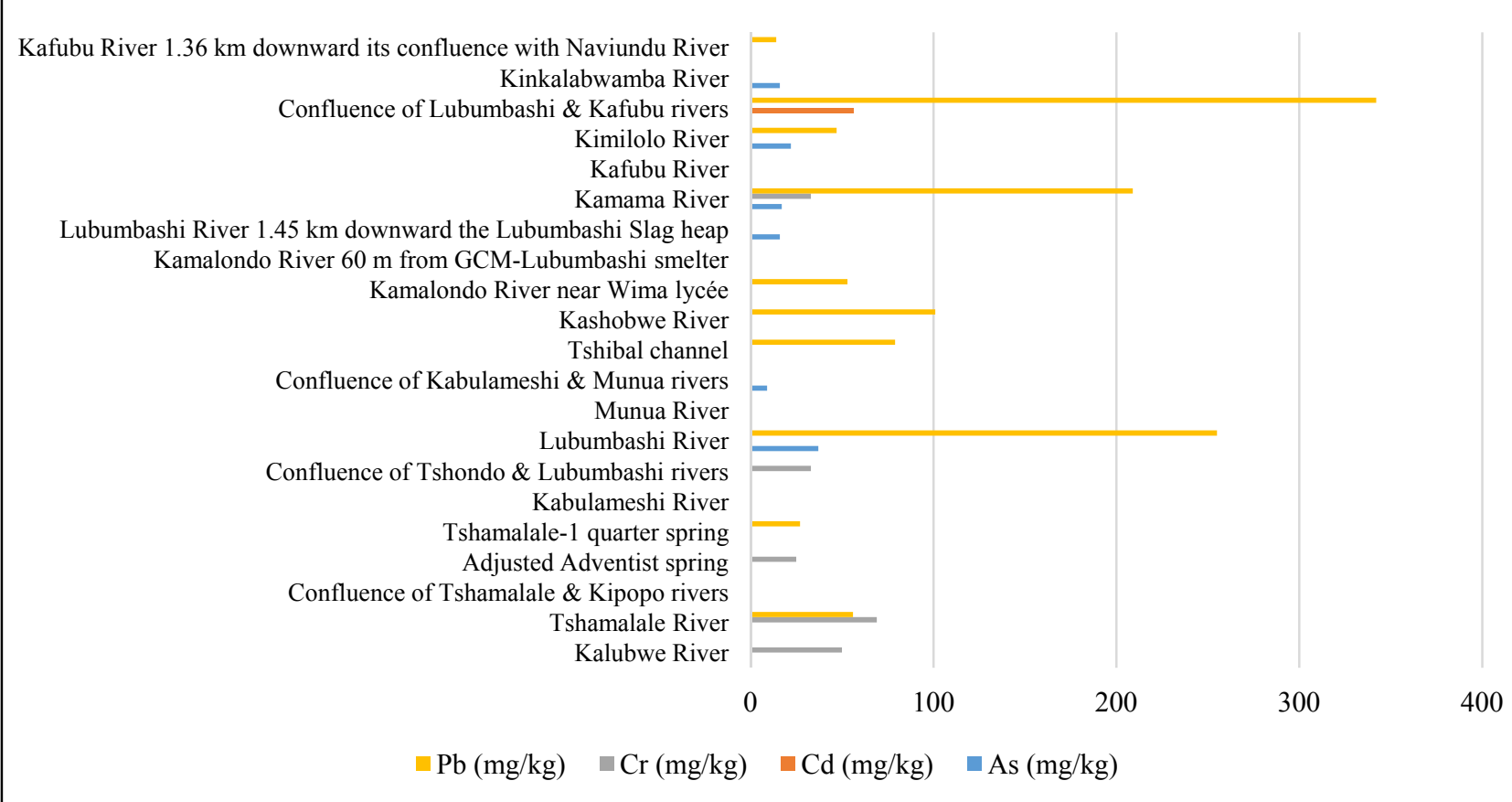

Fig. 2 Concentrations of $\mathrm{As}, \mathrm{Cd}, \mathrm{Cr}$ and $\mathrm{Pb}$ in sediment samples from the Lubumbashi river basin, Kafubu, Kimilolo and Kinkalabwamba rivers $\left(\mathrm{mg} \cdot \mathrm{kg}^{-1} \cdot \mathrm{dw}\right)$ in Lubumbashi city during February, March and April 2016.

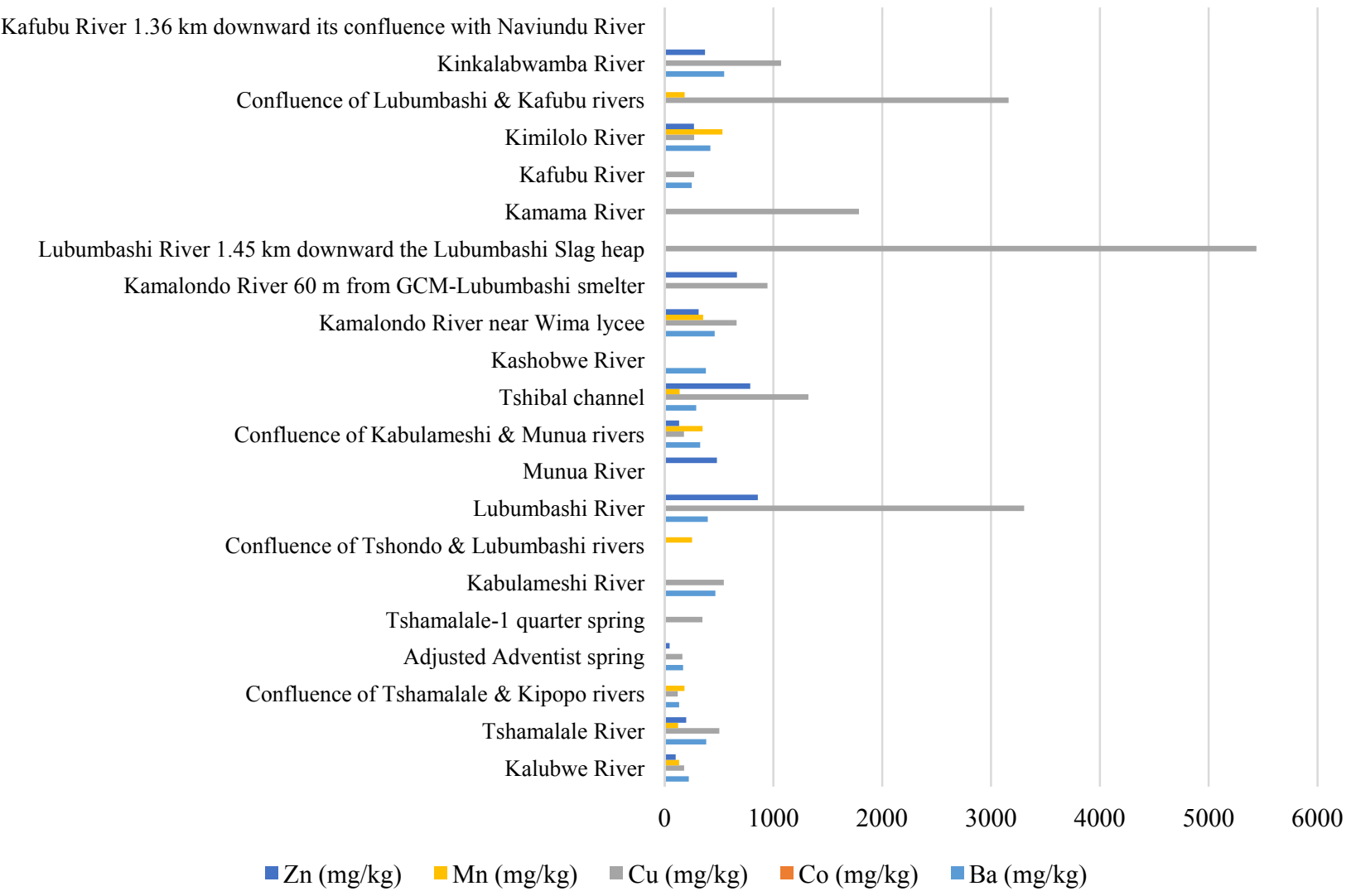

Fig. 3 Concentrations of $\mathrm{Ba}, \mathrm{Co}, \mathrm{Cu}, \mathrm{Mn}$ and $\mathrm{Zn}$ in sediment samples from the Lubumbashi river basin, Kafubu, Kimilolo and Kinkalabwamba rivers $\left(\mathrm{mg} \cdot \mathrm{kg}^{-1} \cdot \mathrm{dw}\right)$ in Lubumbashi city during February, March and April 2016. 
$\mathrm{Fe}, \mathrm{Pb}$ and $\mathrm{Zn}$ concentrations noted in Mvudi river sediments [3] were much lower than those respectively found in sediments of most rivers of the Lubumbashi river basin, as well as Kafubu, Kimilolo and Kinkalabwamba rivers. Only Mn concentrations noted in sediments of Mvudi river [3] were higher than those recorded in this study, except those in sediments samples from the confluence of Tshondo and Lubumbashi rivers $\left(433.5 \mathrm{mg} \cdot \mathrm{kg}^{-1}\right)$, and from Kimilolo river $\left(531 \mathrm{mg} \cdot \mathrm{kg}^{-1}\right)$. The concentrations of $\mathrm{Cu}, \mathrm{Pb}$ and $\mathrm{Zn}$ reported by the same authors [37] were significantly lower than those respectively recorded in sediments of most rivers of the Lubumbashi river basin, Kafubu, Kimilolo and Kinkalabwamba rivers in Lubumbashi city. On the other hand, the mean concentrations of $\mathrm{Zn}$ found in sediments of Tshibal channel $(787$ $\left.\mathrm{mg} \cdot \mathrm{kg}^{-1} \cdot \mathrm{dw}\right)$, Kamama river $\left(845.5 \mathrm{mg} \cdot \mathrm{kg}^{-1} \cdot \mathrm{dw}\right)$, Tshondo and Lubumbashi rivers' confluence (856 $\left.\mathrm{mg} \cdot \mathrm{kg}^{-1} \cdot \mathrm{dw}\right)$, Tshondo river $\left(895.5 \mathrm{mg} \cdot \mathrm{kg}^{-1} \cdot \mathrm{dw}\right)$, Lubumbashi river 1.45 kilometer downward the Lubumbashi Slag heap $\left(1,342.5 \mathrm{mg} \cdot \mathrm{kg}^{-1} \cdot \mathrm{dw}\right)$, and Kafubu river at its confluence with Lubumbashi river $\left(1,534.5 \mathrm{mg} \cdot \mathrm{kg}^{-1} \cdot \mathrm{dw}\right)$ were much higher than those noted in sediments of Winterbeek river (Belgium) [38]. Also, sediment mean concentrations of $\mathrm{Cd}$ at the confluence of Lubumbashi river with Kafubu river (56 $\left.\mathrm{mg} \cdot \mathrm{kg}^{-1} \cdot \mathrm{dw}\right), \mathrm{Pb}$ in Tshibal channel $\left(79 \mathrm{mg} \cdot \mathrm{kg}^{-1} \cdot \mathrm{dw}\right)$, Kamalondo river 60 meters from the GCM-Lubumbashi smelter (100.5 $\left.\mathrm{mg} \cdot \mathrm{kg}^{-1} \cdot \mathrm{dw}\right)$, Kalubwe river $\left(101 \mathrm{mg} \cdot \mathrm{kg}^{-1} \cdot \mathrm{dw}\right)$, Lubumbashi river 1.45 kilometer downward the Lubumbashi Slag heap $\left(146.5 \mathrm{mg} \cdot \mathrm{kg}^{-1} \cdot \mathrm{dw}\right)$, at the confluence of Kamama river with Lubumbashi river $\left(209 \mathrm{mg} \cdot \mathrm{kg}^{-1} \cdot \mathrm{dw}\right)$, that of Tshondo river with Lubumbashi river $\left(255 \mathrm{mg} \mathrm{kg}^{-1} \mathrm{dw}\right)$, in Tshondo river $\left(240.5 \mathrm{mg} \cdot \mathrm{kg}^{-1} \cdot \mathrm{dw}\right)$ and at the confluence of Lubumbashi river with Kafubu river (342 $\left.\mathrm{mg} \cdot \mathrm{kg}^{-1} \cdot \mathrm{dw}\right)$, were higher than those respectively reported for the sediments of Winterbeek river [38].

The mean $\mathrm{Cu}$ concentrations in sediments of all the studied rivers, channel and springs in Lubumbashi city (except at the confluence of water from both springs with Tshamalale river) were much higher than the concentrations of that metal reported for Winterbeek river sediments [38]. The sediment mean concentrations of $\mathrm{Cr}$ in Kinkalabwamba river $\left(174.5 \mathrm{mg} \cdot \mathrm{kg}^{-1} \cdot \mathrm{dw}\right)$, Co in Lubumbashi river 1.45 kilometer downward the Lubumbashi Slag heap $\left(902.5 \mathrm{mg} \cdot \mathrm{kg}^{-1} \cdot \mathrm{dw}\right), \mathrm{Cu}$ in Kimilolo river $\left(271 \mathrm{mg} \cdot \mathrm{kg}^{-1} \cdot \mathrm{dw}\right)$, Kafubu river $(272$ $\left.\mathrm{mg} \cdot \mathrm{kg}^{-1} \cdot \mathrm{dw}\right)$, Tshamalale-1 quarter spring (347 $\left.\mathrm{mg} \cdot \mathrm{kg}^{-1} \cdot \mathrm{dw}\right)$, Kabulameshi river $\left(545 \mathrm{mg} \cdot \mathrm{kg}^{-1} \cdot \mathrm{dw}\right)$, Kamalondo river near Wima Lycée $\left(661 \mathrm{mg} \cdot \mathrm{kg}^{-1} \cdot \mathrm{dw}\right)$, Kashobwe river $\left(682.5 \mathrm{mg} \cdot \mathrm{kg}^{-1} \cdot \mathrm{dw}\right)$, Kamalondo river 60 meters from the GCM-Lubumbashi smelter (946 $\left.\mathrm{mg} \cdot \mathrm{kg}^{-1} \cdot \mathrm{dw}\right), \quad$ Kinkalabwamba river $(1,070$ $\left.\mathrm{mg} \cdot \mathrm{kg}^{-1} \cdot \mathrm{dw}\right)$, Tshibal channel $\left(1,321 \mathrm{mg} \cdot \mathrm{kg}^{-1} \cdot \mathrm{dw}\right)$, Munua river $\left(1,630.5 \mathrm{mg} \cdot \mathrm{kg}^{-1} \cdot \mathrm{dw}\right)$, Lubumbashi river at its confluence with Kamama river $(1,786$ $\mathrm{mg} \cdot \mathrm{kg}^{-1} \cdot \mathrm{dw}$ ), Kafubu river at its confluence with Lubumbashi river $\left(3,161 \mathrm{mg} \cdot \mathrm{kg}^{-1} \cdot \mathrm{dw}\right)$, Lubumbashi river at its confluence with Tshondo river $(3,304$ $\left.\mathrm{mg} \cdot \mathrm{kg}^{-1} \cdot \mathrm{dw}\right)$, Tshondo river $\left(3,467.5 \mathrm{mg} \cdot \mathrm{kg}^{-1} \cdot \mathrm{dw}\right)$ and Lubumbashi river 1.45 kilometer downward the Lubumbashi Slag heap $\left(5,438 \mathrm{mg} \cdot \mathrm{kg}^{-1} \cdot \mathrm{dw}\right)$ were respectively much higher than the respective $\mathrm{Cr}$, Co, $\mathrm{Cu}, \mathrm{Zn}$ and $\mathrm{Pb}$ concentrations reported for the most polluted sediments of the Tisza river, Hungary [13].

Combined with the low (acid) $\mathrm{pH}$ of the water and the low OM contents of sediments in most of the studied rivers, those sediment metal levels largely exceeding the SQGs' probable effect level values increase the metal risk for aquatic organisms living in those rivers, and for the health of people who depend on those rivers to meet their water supply, irrigation and recreational needs.

The high trace metal contamination of sediments in the Lubumbashi river basin, Kafubu, Kimilolo and Kinkalabwamba rivers might be partially due to urban, hospital and domestic waste dumped in rivers and channel, run off from metal-rich soils and mostly to artisanal and industrial mining activities with emphasis on the GCM-Lubumbashi smelter and the Lubumbashi Slag heap. Untreated hospital effluents have been 
shown to contribute to the accumulation of toxic metals in sediments of receiving systems [39]. Solid waste and untreated effluents from all those activities, atmospheric deposition from the smelters and the slag heap to the rivers, channel, springs and soils, as well as rain that runs off metal-contaminated soils into various rivers and channel account for so high trace metal levels of the studied sediments. It has been reported that in various hydrometallurgical and smelter plants, copper and cobalt extraction is accompanied with discharge of by-products rich in $\mathrm{Zn}, \mathrm{Pb}, \mathrm{As}, \mathrm{Cd}$ or sulfur compounds [40]. Atmospheric fallout from the $\mathrm{SO}_{2}$-rich fumes discharged through the chimney of the GCM-Lubumbashi smelter contributed to metal accumulation in the soils of Penga-Penga plateau in Lubumbashi city, and the exploitation of quartz and brick-making contributed to the remobilization of trace metals through the landscape, soil, air and water [29]. Also, during the rainy season, hydromorphic soils in the Lubumbashi city bottom valleys collect waste enriched with trace metals from various plants all around the city, ore-washing carried out by artisanal mining exploiters in their residential parcels, malachite jewellery-making scattered in the city quarters and from a layer of slag spread on avenues to combat dust during dry season and mud during rainy season [41].

\section{Conclusion}

The results of the current study proved that sediments of the Lubumbashi river basin, Kafubu, Kimilolo and Kinkalabwamba rivers are heavily contaminated with trace metals, such as $\mathrm{As}, \mathrm{Ba}, \mathrm{Cd}, \mathrm{Co}$, $\mathrm{Cr}, \mathrm{Cu}, \mathrm{Fe}, \mathrm{Mn}, \mathrm{Pb}$ and $\mathrm{Zn}$. The highest mean levels of $\mathrm{Cu}$ and $\mathrm{Co}$ were recorded in sediments of Lubumbashi river 1.45 kilometer downward the Lubumbashi Slag heap, those of $\mathrm{Cd}, \mathrm{Pb}$ and $\mathrm{Zn}$ were found in sediments at the confluence of Lubumbashi river with Kafubu river, and those of $\mathrm{Ba}, \mathrm{Cr}$ and $\mathrm{Fe}$ were noted in sediments of Kinkalabwamba river, whereas those of $\mathrm{Mn}$ and As were respectively registered in sediments of Kimilolo river and at the confluence of Tshondo river with Lubumbashi river. Mean levels of As, Cd, $\mathrm{Cr}, \mathrm{Cu}, \mathrm{Pb}$ and $\mathrm{Zn}$ in most sediments of the Lubumbashi river Basin, Kafubu, Kimilolo and Kinkalabwamba rivers exceed the respective TEL values and PEL values of the Canadian SQGs. They are at risk for aquatic organisms of the concerned rivers and for human beings who live along those rivers, especially that low $\mathrm{pH}$ and sediment organic matter contents make the metals more available for bioaccumulation in most of the rivers. Trace metal contamination of sediments in the studied rivers, channel and springs in Lubumbashi city might be partially attributed to natural processes, unplanned urbanization and poor waste management and mostly to abandoned and ongoing mining and ore processing activities.

Authors suggest that (i) the provincial and national governments strictly implement the Congolese Mining Regulations for better protection of the environment; (ii) swimming in the rivers at heavily polluted sites be forbidden; and (iii) environmental monitoring of the rivers be regularly carried out and provincial authorities be informed of the results to let them take adequate protection measures for the population.

\section{Acknowledgements}

The authors are thankful to Julie Mwehu for her participation in sampling campaigns and Trésor Kisimba for sample handling and preservation in the laboratory.

\section{References}

[1] Pradit, S., Wattayakorn, G., Angsupanich, S., Baeyens, W., and Leermakers, M. 2010. "Distribution of Trace Metal Elements in Sediments and Biota of Songkhla Lake, Southern Thailand." Water, Air and Soil Pollution 206 (1-4): 155-74.

[2] Salomons, W. 1998. "Biogeodynamics of Contaminated Sediments and Soils: Perspectives for Furture Research." Journal of Geochemical Exploration 62 (1): 37-40.

[3] Edokpayi, J. N., Odiyo, J. O., Popoola, O. E., and Msagati, T. A. 2016. "Assessment of Trace Metals Contamination of Surface Water and Sediment: A Case 
Study of Mvudi River, South Africa.” Sustainability 8 (2): 135.

[4] Varol, M., and Sen, B. 2012. "Assessment of Nutrient and Heavy Metal Contamination in Surface Water and Sediments of the Upper Tigris River, Turkey." Catena 92: 1-10.

[5] Von der Heyden, C. J., and New, M. G. 2004. "Sediment Chemistry: A History of Mine Contaminant Remediation and an Assessment of Processes and Pollution Potential." Journal of Geochemical Exploration 82 (1): 35-57.

[6] Baeyens, W., Meuleman, C., Muhaya, B., and Leermakers, M. 1998. "Behaviour and Speciation of Mercury in the Scheldt Estuary (Water, Sediments and Benthic Organisms)." Trace Metals in the Westerschelde Estuary: A Case Study of a Polluted, Partially Anoxic Estuary. Springer Netherlands, 63-79.

[7] Muhaya, B. B., Leermakers, M., and Baeyens, W. 1997. "Total Mercury and Methylmercury in Sediments and in the Polychaete Nereis Diversicolor at Groot Buitenschoor (Scheldt Estuary, Belgium)." Water, Air and Soil Pollution 94 (1): 109-23.

[8] Park, J., and Presley, B. J. 1997. "Trace Metals Contamination of Sediments and Organims from the Swan Lake Area of Galveston Bay." Environmental Pollution 98 (2): 209-21.

[9] Mees, F., Maselehdani, M. N. N., De Putter, T., D’Hollander, C., Van Biezen, E., Mujinya, B. B., et al. 2013. "Concentrations and Forms of Heavy Metals around Two Ore Processing Sites in Katanga, Democratic Republic of Congo." Journal of African Earth Sciences 77: 22-30.

[10] Katemo, B. M., Collinet, G., André, L., Chocha, A. M., Marquet, J. P., and Micha, J. C. 2010. "Assessment of Food Chain Contamination with Trace Elements $(\mathrm{Cu}, \mathrm{Co}$, $\mathrm{Zn}, \mathrm{Pb}, \mathrm{Cd}, \mathrm{U}, \mathrm{V}$ and $\mathrm{As}$ ) in the Upper Lufira Basin (Katanga, R.D. Congo)." Tropicultura 28 (4): 246-52.

[11] McCauley, D. J., DeGraeve, G. M., and Linton, T. K. 2000. "Sediment Quality Guidelines and Assessment: Overview and Research Needs." Environmental Science \& Policy 3: 133-44.

[12] Salomons, W., and Forstner, U. 1984. Metals in the Hydrocycle. Berlin: Springer.

[13] Nguyen, H. L., Braun, M., Szaloki, I., Baeyens,W., Van Grieken, R., and Leermakers, M. 2009. "Tracing the Metal Pollution History of the Tisza River through the Analysis of a Sediment Depth Profile." Water, Air and Soil Pollution 200 (1-4): 119-32.

[14] South African Water Research Commission. 2014. "Water and the Environment." Water Wheel 13: 8-14.

[15] Mendil, D., and Uluözlü, O. D. 2007. "Determination of Trace Metal Levels in Sediments and Five Fish Species from Lakes in Tomat, Turkey." Food Chemistry 101 (2):
739-45.

[16] Wepener, V., Van Vuren, J. H. J., and Du Preez, H. H. 2001. "Uptake and Distribution of a Copper, Iron and Zinc Mixture in Gill, Liver and Plasma of a Freshwater Teleost, Tilapia Sparrmanii." Water SA 27 (1): 99-108.

[17] Von Gunten, H. R., Sturm, M., and Moser, R. N. 1997. "200-year Record of Metals in Lake Sediments and Natural Background Concentrations." Environmental Science and Technology 31 (8): 2193-7.

[18] Forstner, U., and Wittmann, G. T. W. 1983. Metal Pollution in the Aquatic Environment. Berlin: Springer.

[19] Edokpayi, J. N., Odiyo, J. O., and Olasoji, S. O. 2014. "Assessment of Heavy Metal Contamination of Dzindi River, in Limpopo Province, South Africa." International Journal of Natural Science Research 2 (10): 185-94.

[20] Charriau, A., Lesven, L., Gao, Y., Leermakers, M., Baeyens, W., Billon, G., et al. 2011. "Trace Metal Behavior in Riverine Sediments: Role of Organic Matter and Sulfides." Applied Geochemistry 26 (1): 80-90.

[21] Caetano, M., Madureira, M. J., and Vale, C. 2003. "Metal Remobilisation during Resuspension of Anoxic Contaminated Sediment: Short-term Laboratory Study." Water, Air and Soil Pollution 143 (1): 23-40.

[22] Cantwell, M. G., Burgess, R. M., and Kester, D. R. 2002. "Release and Phase Partitioning of Metals from Anoxic Estuarine Sediments during Periods of Simulated Resuspension." Environmental Science and Technology 36 (24): 5328-34.

[23] Saulner, I., and Mucci, A. 2000. "Trace Metal Remobilization Following the Resuspension of Estuarine Sediments: Saguenay Fjord, Canada." Applied Geochemistry 15 (2): 191-210.

[24] Kashimbo, S. K., Mbikayi, E., Shutcha, M. N., and Lukens, L. 2015. "Evaluation of Trace Metal Element Contamination Risk of Food Chain of Three Garden Crop Species Cultivated along Lubumbashi River (Katanga, D.R. Congo)." International Journal of Innovation and Applied Studies 10 (4): 1125-33.

[25] Jadia, C. D., and Fulekar, M. H. 2009. "Phytoremediation of Heavy Metals: Recent Techniques." African Journal of Biotechnology 8 (6): 921-8.

[26] Sardar, K., Ali, S., Hameed, S., Afzal, S., Fatima, S., Shakoor, M. B., et al. 2013. "Heavy Metals Contamination and What Are the Impacts on Living Organisms." Greener Journal of Environmental Management and Public Safety 2 (4): 172-9.

[27] Atibu, E. K., Devarajan, N., Thevenon, F., Poté, J., Tshibanda, J. B., Mpiana, P., et al. 2013. "Concentration of Metals in Surface Water and Sediment of Luilu and Musonoie Rivers, Kolwezi-Katanga, Democratic Republic of Congo." Applied Geochemistry 39: 26-32.

[28] Muhaya, B. B., Numbi, R. M., Lubala, F. T., Mugisho, J. 

Kimilolo and Kinkalabwamba Rivers in Lubumbashi City, Democratic Republic of Congo

B., and Tshibanda, D. K. 2015. "Heavy Metal Contamination of Well Water in the Kipushi Mining Town (Democratic Republic of Congo)." Journal of Environmental Science and Engineering B 4 (8): 403-18.

[29] Kashimbo, S. K. 2016. "Influence of Surface States on the Distribution of Trace Metals in the Soil Landscape: Case of Penga-Penga (Lubumbashi, Upper-Katanga, D.R. Congo)." International Journal of Innovation and Scientific Research 23 (2): 326-35.

[30] Muhaya, B. B., Bukas, A., Lubala, F. T., Kaseti, P. K., and Mugisho, J. B. 2016. "Assessment of Trace Metals in Soils of North-Eastern Lubumbashi (Upper-Katanga Province, Democratic Republic of Congo)." Journal of Environmental Science and Engineering A 5 (9): 452-62.

[31] Mohiuddin, K. M., Ogawa, Y., Zakir, H. M., Otomo, K., and Shikazono, N. 2011. "Heavy Metals Contamination in Water and Sediments of an Urban River in a Developing Country." International Journal of Environmental Science and Technology 8 (4): 723-36.

[32] Samarghandi, M., Nouri, J., Mesdaghinia, A. R., Mahvi, A. H., Nasseri, S., and Vaezi, F. 2007. "Efficiency Removal of Phenol, Lead and Cadmium by Means of $\mathrm{UV} / \mathrm{TiO}_{2} / \mathrm{H}_{2} \mathrm{O}_{2}$ Processes." International Journal of Environmental Science and Technology 4 (1): 19-25.

[33] Canadian Council of Ministers of the Environment. 2001. "Canadian Sediment Quality Guidelines for the Protection of Aquatic Life: Summary Tables. Canadian Environmental Quality Guidelines, 1999.” Canadian Council of Ministers of the Environment: Winnipeg, MB, Canada.

[34] Van Ranst, E., Verloo, M., Demeyer, A., and Pauwels, J. M. 1999. Manual for the Soil Chemistry and Fertility Laboratory: Analytical Methods for Soils and Plants Equipment and Consumables. University of Gent, Gent, Belgium.

[35] Violante, A., Cozzolino, V., Perolomov, L., Caporale, A. G., and Pigna, M. 2010. "Mobility and Bioavailability of
Heavy Metals and Metalloids in Soil Environments." Journal of Soil Science and Plant Nutrition 10 (3): 268-92.

[36] Muhaya, B. B. M., Joiris, C. R., Leermakers, M., Deronde, L., Bossicart, M., and Baeyens, W. 1993. "Total Mercury and Methylmercury in Soils, Litter and Plants from the Zoniën (Soignes) Forest (Brussels, Belgium)." In Biological Indicators of Global Change: BIGC Symposium, Brussels, 7-9 May, 1992, 247.

[37] Lesven, L., Gao, Y., Billon, G., Leermakers, M., Ouddane, B., Fischer, J. C., et al. 2008. "Early Diagenetic Processes Aspects Controlling the Mobility of Dissolved Trace Metals in Three Riverine Sediment Columns." Science of the Total Environment 407 (1): 447-59.

[38] Gao, Y., Baeyens, W., De Galan, S., Poffijn, A., and Leermakers, M. 2010. "Mobility of Radium and Trace Metals in Sediments of the Winterbeek: Application of Sequential Extraction and DGT Techniques." Environmental Pollution 158 (7): 2439-45.

[39] Mubedi, J. I., Devarajan, N., Le Faucheur, S., Mputu, J. K., Atibu, E. K., Sivalingam, P., et al. 2013. "Effects of Untreated Hospital Effluents on the Accumulation of Toxic Metals in Sediments of Receiving System under Tropical Conditions: Case of South India and Democratic Republic of Congo." Chemosphere 93 (6): 1070-6.

[40] Shutcha, M. N., Mpundu, M. M., Faucon, M. P., Meerts, P., Visser, M., Colinet, G., et al. 2010. "Phytostabilisation of Copper Contaminated Soil in Katanga: An Experiment with Three Native Grasses and Two Amendments." International Journal of Phytoremediation 12 (6): 616-32.

[41] Mpundu, M. M., Yannick, U. S., Theodore, M. M., Guy, K. M., Muyembe, M., Kampanyi, I., et al. 2013. "Determination of Levels of Trace Metals in Soils of Kitchen gardens in the Mining Town of Lubumbashi and the Risks of Contamination of Vegetable Crops." Journal of Applied Biosciences 65: 4957-68. 